\title{
TRADITIONAL ART KAYORI AS AN IDENTITY OF TAA SOCIETY IN DISTRICT OF TOJO UNA-UNA IN GLOBALIZATION ERA
}

\author{
${ }^{\otimes}$ Abdul Rasyid Hasan \\ Art-Education Postgraduate Program, Semarang State University \\ ${ }^{\square}$ Bendan Dhuwur Campus, Semarang Indonesia \\ E-mail: papatyazh@gmail.com
}

Received: November 15, 2015. Revised: November 29, 2015. Accepted: December 4, 2015

\begin{abstract}
Kayori is someone's or group's statement expressed civilly in a particular time, so that the messages delivered are easily internalized and understood to nod in agreement. This research intends to identify form, function, and meaning contained in kayori traditional art of Taa society. This research employed qualitative method with a cultural approach. The results of this study portray that kayori performance periodically held is an introduction media in increasing public awareness. Kayori, embracing aesthetic values, functions to diffuse moral and aesthetic aspects to the society. Education in kayori tradition follows the regeneration process in to society orientating towards the new roles for young generation to maintain their cultural heritages. Kayori tradition implies valuable meaning of life and provides chance in understanding historical cultural heritages in tackling down recent issues in Taa society.
\end{abstract}

Keywords: identity; kayori; Taa ethnic group; Tojo Una-Una

How to Cite: Hasan, A. (2015). Traditional Art Kayori as An Identity of Taa Society in District of Tojo Una-Una in Globalization Era. Harmonia: Journal of Arts Research and Education, 15(2), 133-137. doi:http://dx.doi.org/10.15294/ harmonia.v15i2.4427

\section{INTRODUCTION}

Art is one of universal cultural systems lying on world's society. One kind of arts holding important role in society is traditional arts. Cultural sacredness and traditional arts lie on people's appreciation for their histories - not the objects appreciated. From the historical perspective, traditional arts are critical historical sources containing sustainability, dynamics, and identities of the owner. Meanwhile, traditional arts, culturally become a mode transmitting values across generations. Traditional arts are arts living inherently in society. They are humans' works including their mindset either personally or collectively. Concerning on such issue, Ka- yam (1981: 39) asserts that:

"Arts cannot be separated from society, as one of the most important parts in culture. The arts represent creativity of the culture".

Art in human's life is the characteristic of a region in which by performing arts people are able to recognize cultures growing and developing based on custom values applied in their region. Diversity of traditional arts growing and developing in a region becomes an asset and the pride of the supporting society as well as characteristic of their region. As stated by acclaimed anthropologist, E.B Tylor in his book entitled Primitive Culture published in 1924, culture is a complexity embracing knowledge, belief, art, morality, law, 
custom, ability, and behavior acquired by humans as a member of society (Sulasman and Gumilar, 2013, p. 17).

District of Tojo Una-Una which was part of the Poso district contains a great deal of cultural uniqueness coming from local people's customs, and it becomes pride in the middle of society such as malaolita, main kantar, karatu, mentompo, tende bomba, ganda potaru, mailogo, baku binti, main gasing, and padungku in addition to diverse musical instruments such as geso-geso, $k a-$ pondo, senggona, talalo, lalove, and flute. Unfortunately, the priceless abundance of arts is not well-maintained, and more seriously it is ignored by society - one of which is traditional art of kayori.

Kayori art, as a part of local wisdoms considered the reality of alternative cultural value stands in two local-cultural systems. National-cultural values are universally applied for the nation as well as the ones outside another local-cultural boundaries. Values of local wisdom by all means represent Indonesia as they are combined with other values that in fact are transmitted from values of local cultures.

This research tries to describe the existence of kayori tradition in terms of its existence in Taa society in the district of Tojo Una-Una. Kayori is closely related to values and norms which become a social keystone in the scope of of society. This research is a qualitative study of the cultural paradigm towards problems concerning on form, function, and meaning of kayori, in which kayori, in its rhymes is multi-dimensional and meaningful.

\section{METHOD}

The research method employed in this context was qualitative-descriptive study. Qualitative research is always descriptive, which means that type of data analyzed and the results of the analysis are descriptive in terms of the observed phenomena - not numbers or coefficients of variable relation. Based on the issue investigated, this research aims to describe form, function, and meaning of kayori art in Tojo Una-Una district.

To conduct this research, I limited the observed regions which consisted of Sub-district of Ampana and Ampana Tete, district of Tojo Una-Una, and province of Central Sulawesi. These locations were chosen under some considerations that (1) kayori performers were generally found in these locations (sub-district of Ampana and Ampana Tete); (2) Both sub-districts (Ampana and Ampana Tete), had represented overall behaviors of Taa society in transmitting and utilizing traditional arts.

Choosing data and source of data were conducted by random-sampling technique. Data of this research were interpretative, so interactive analysis was employed in some stages - reducing the data, presenting the data, and verifying the data (Miles \& Huberman, 1992) p.17-18)

\section{DISCUSSION}

From observations conducted, it can be stated that kayori art is not representation of local culture any longer. This was caused by some factors such as (1) young generation considered that oral tradition has been antiquated with current development. Such stigma has been internalized in the youth's mind considering that oral tradition is suitable for the older generation; (2) technology, which developing rapidly became an indicator of oral-tradition degradation. Young generation tended to read comics, watch television, playing interactive games, Facebook, etc. instead of listening to stories or advices from the elders which were not drawn to their eyes. In other words, printed and electronic media have become such an attractive medium instead of learning or listening to oral tradition.

According to Kusno K. Rengka, the chief of the Pusingi village in the buddistrict of Ampana Tete, "Nowadays kayori tradition has been rarely held, and if it was carried out, it was different from the one in 30 years ago" (interview on May $30^{\text {th }} 2015$ ). Based on his explanation, performance of kayori art functioned as entertainment me- 
ans for the society of Tojo Una-Una since the past. Whenever kayori was performed, people visited the crowd to listen to kayori performed. The elders, children, and even youth did not want to miss the chance. In such condition, kayori functions as a means for meeting with the others, so the chance could be used to assemble the mass. By kayori, we were able to provide developmental information, religion, and advices. For the youth, having such chance could be used to broaden the society. More importantly, it was an initial stage to find true love.

Kayori intoned particular rhymes accompanied by dance performed by some men and women. Oral tradition of kayori was crooned, listened, and internalized together in a particular event. The events were related to the wedding reception, harvest festival, cultivation festival, and other events. Kayori contained ideas, thought, doctrine, advices, and moral values. These ideas influenced attitudes and behavior of traditional society who had close collectivity relation. The existence of this localcultural product was considered as a historical proof of public's creativity which could be utilized to increase solidarity.

The spirit of solidarity realized in kayori has positively impacted on strengthening inner thoughts among society members. In this context, it can be seen that kayori (oral tradition) has a social function, as well. Thus, it can be said that degradation of kayori in the society was an indication of degradation of social relation among the society members, and vice versa. This statement frequently appears on cultural observers who judge that socio cultural relation of a society has moved into individualistic and compormistic - no any longer reflection and representation of cultural system internalized in traditional society.

When the kayori is performed (requiting poem) or when the women sing the rhymes, the men have to listen and think about what they are going to answer. The core value of kayori is public discussion to reach agreement. The rhymes used in eve- ry turn are different - depending on the event. Anyone is welcomed to join kayori as long as he/she is able to follow the movements. Kayori is commonly held in field, market, or baruga (place in which the elders/religious leaders assemble), and they perform kayori after praying Isya'; at $8 \mathrm{PM}$ till midnight.

Kayori is identical to padungku. It is yearly rice-harvest celebration. Thus, whenever padungku is held, it will be blissfully cerebrated. Before padungku is held, pre-aranduku or prakodi is carried out in which the farmer who has intents will sacrifice 2 or three chickens as needed, and their blood will be put on grains of rice which have been cut in the barn in order to avoid any dangers. People say when such ritual is not carried out, the farmers suffer deaf like being punctured by needles.

Once series of activities are finished, there will be held padungku which represents being grateful for mercies. In the middle of this event, there will be snipping-top playing, bakubinti (for men only), and mailogo. The major event of all activities is kayori (requiting poem) which intends to discuss the time to cultivate. Once the agreement is reached, kayori will immediately end.

Characteristics of kayori takes place on the way of communication in requiting poem between men's group and the women's group. The language used in kayori is expressed poetically and metaphorically, combined with particular movements, as well. The way people communicate in kayori requires skills in switching the rhymes. The truth and information expressed in communication represent individual quality arranged in a united pattern. Hence, communication in kayori can apply the informative and communicative functions.

According to Mr. Asriman (interview on May $18^{\text {th }}$ 2015), he stated things related to local identities of Taa society in which they have to be developed and raised - one of the ways is performing kayori in addition to local language, traditional clothes, and history. Good appearance of local 
language, traditional clothes, and history affect the identity of Taa society. Basic values of their cultures are slowly replaced by values coming from products of global culture. It was also asserted by Kusno K. Rengka (interview on May 24th, 2015). In comporting perception with the meaning of Minang, the society of Taa has been different in terms of performance as social identity of Taa. Therefore, it is required efforts from the government, such in the following statement.

"Talking about custom (meaning) of Minang, we; as the society of Taa, has not reached an agreement! Why? Because we are never included in the discussion. They are only urban society who does not know about the customs of Taa. We have to achieve equal perception related to tradition since Taa is part of our identities, especially the ones related to custom.

The statement above represents that developing identities in the society of Taa, which has not been realized in understanding, still requires efforts to find out the cultural core or cultural value system. This phenomenon is in accordance with what is stated by Storey $(2007$, p. 4$)$ that cultural value system is a guide for the society to develop potency and dynamics in social life. Cultures help developing structure and creating history in society.

Acceptance, welcoming, response, reaction, and attitudes of the Taa society towards the meaning implied in kayori rhymes have never appeared in the surface. Kayori is only known as oral tradition, but the society does not understand the form of oral tradition. In the society of Taa, oral tradition of kayori is only recognized by a few groups of people - those who are aged. Young generation is pessimistic about oral tradition. There is no such intention to learn and deepen the understanding of meanings implied in this oral tradition.

Preserving kayori tradition by both societies of tea and the government implies educative meaning. This occurs as by conducting preservation efforts of kayori tradition as explained above, the society who recently has lack of understanding oral tradition is expected to gain new understanding and understand their rights as well as responsibilities as inheritors of an oral tradition. In addition, the government will receive suggestions which can be used as guide in carrying the following works. Educative process is a process of transmitting values, attitudes, and beliefs in which the existence of cultural system is believed, and its function as it does. Moreover, educative process contains the process of implementing regeneration values as stated by Redfield (in Widja, 1993, p. 53). In other words, in this process, there is emphasis on discontinuity function, but it implies the function of preserving cultural values owned by the society.

From the explanation above, it has been clear that educative meaning in preserving oral traditions of kayori follows a regeneration process in the society of Taa. Kayori tradition purposes to imply new messages for the young generation to preserve their cultural heritages even though there are aspects changing in cultural life. This is in accordance with preservation concept which intrinsically contains the cultural dynamic elements

\section{CONCLUSIONS}

According to the explanation, it can be concluded that the existence of oral tradition has been significantly replaced by products of global culture. This condition will impact on stopping cultural heritages which are factually occurring. If this thing is ignored, one of local cultural product which is priceless will disappear. Therefore, it requires efforts in preserving traditional art kayori periodically. The government and society have to maintain and preserve the balance between the continuity and changes, so kayori art will always appear. Appreciation improvement of the society will provide a big chance for development of kayori which is threatened by products of global cultures. Tradition of kajori has benefits which can influence national cultural structures since kayori is aestheticsymbolic product based on sociocultural 
Abdul Rasyid Hasan, Traditional Art Kayori as An Identity of Taa Society in District of Tojo 137

experiences of the society. This preservation effort is carried out gradually through a process of internalization, socialization, and implementation.

\section{REFERENCE}

Kayam, U. (1981). Seni Tradisi Masyarakat. Jakarta: PT Djaya Pirusa.

Miles, H B., Heberman A M. (1992). Analisis Data Kualitatif translated by Tjetjep Rohendi Rohidi. Jakarta: UI Press.

Moleong, L. J. (2009). Metode Penelitian
Kualitatif. Bandung: PT. Remaja Rosdakarya.

Storey, J. (2007). Cultural Studies dan Kajian Budaya Pop. Yogyakarta \& Bandung: Jalasutra.

Sulasman \& Gumilar. (2013). Teori-teori Kebudayaan. Bandung: CV Pustaka Setia

Widja, I G. (1993). "Pelestarian Budaya: Makna dan Implikasi dalam Proses Regenerasi Bangsa". dalam Kebudayaan dan Kepribadian Bangsa. Denpasar: PT. Upada Sastra 